\title{
Perancangan Sistem Pendukung Keputusan Penentuan Impor Bawang Merah
}

\author{
Wiwi Widayani*1, Kusrini ${ }^{2}$, Hanif Al Fatta ${ }^{3}$ \\ ${ }^{1,2}$ STMIK AMIKOM Yogyakarta \\ ${ }^{3}$ Magister Teknik Informatika STMIK AMIKOM Yogyakarta \\ E-mail: ${ }^{* 1}$ wiwi.w@amikom.ac.id, ${ }^{2}$ kusrini@ amikom.ac.id, ${ }^{3}$ hanif.a@ amikom.ac.id
}

\begin{abstract}
Abstrak
Pertambahan jumlah penduduk Indonesia serta meningkatkannya permintaan industri akan bawang merah yang tidak diimbangi dengan jumlah produksi mendorong pemerintah membuka impor bawang merah. Impor dilakukan untuk menjaga keseimbangan harga dan pasokan bawang merah sehingga inflasi yang diakibatkan kenaikan harga bawang merah dapat ditekan, namun impor yang tidak tepat jumlah akan mengakibatkan kerugian bagi pihak petani, perlu adanya sistem pendukung dalam menentukan volume impor guna menjaga keseimbangan harga pasar dan pemenuhan kebutuhan bawang merah. Sistem pendukung keputusan yang dirancang menerapkan Fuzzy Inference System (FIS) Tsukamoto. Sistem yang dirancang memungkinkan pengguna untuk melakukan training data dan testing data, proses dalam training data yaitu : 1)Clustering data latih, menggunakan algoritma K-Means 2)Ekstraksi Aturan, 3)Testing data latih, hitung nilai impor dengan fuzzy Tsukamoto, 4)Menganalisa error hasil fuzzy menggunakan MAPE(Means Absolute Percentage Error), 5)Testing Data Uji dan menganalisa hasil error data uji. Hasil Uji Model menunjukan penentuan impor bawang merah dengan parameter input harga petani, harga konsumen, produksi, konsumsi, harga impor dan kurs terhadap 60 data latih menghasilkan error terendah sebesar 0.07 pada 12 cluster, hasil uji mesin inferensi terhadap data uji menghasilkan error sebesar 0.25 .
\end{abstract}

Kata Kunci - FIS Tsukamoto, Sistem Pendukung Keputusan, K-Means, Impor Bawang Merah.

Indonesian population growth and increase industrial demand shallot is not matched with number of production prompted the government to opened shallot imports. Import done to maintain the balance price and supply of shallot so inflation caused by rising prices of onion can be suppressed, but not the exact amount of imports would result in losses for the farmers, support system in determining volume imports is need to maintain balance of market price and needs of shallot. Decision support system designed to apply Fuzzy Inference System (FIS) Tsukamoto. The system is allows the user to perform the training data and testing data, the training process performs are: 1) Clustering training data, using the K-Means algorithm 2) Extraction Rule, 3) Testing data, calculate imports value by fuzzy Tsukamoto, 4) analyze the results error using MAPE (Means Absolute Percentage error), 5) testing test data and analyze the results error. The results show the determination of imported shallot with input parameters producer prices, consumer prices, production, consumption, import prices and the exchange rate against 60 training data produces the lowest error of 0:07 in 12 clusters, the inference engine test resulted in an error of 0.25 .

Keywords - FIS Tsukamoto, Decision Support System, K-Means, Import of Shallot. 


\section{PENDAHULUAN}

Bawang merah merupakan komoditas hortikultura yang memiliki nilai ekonomis yang tinggi dan peluang pasar yang besar sebagai bumbu untuk konsumsi rumah tangga, bahan baku industri serta untuk memenuhi kebutuhan ekspor. bawang merah merupakan tanaman sayuran rempah yang cukup populer dikalangan masyarakat. Dalam beberapa tahun terakhir harga bawang merah dalam negeri meningkat akibat adanya kesenjangan antara produksi dengan permintaan dalam negeri selain itu juga karena musim panen (tanam) bawang merah di Indonesia yang tidak menentu diakibatkan oleh gagal panen, sedangkan harga bawang impor CIF (Cost Insurance And Freight) cenderung fluktuatif tidak mengikuti pola tertentu. Pertambahan jumlah penduduk Indonesia serta meningkatkannya permintaan industri akan bawang merah yang tidak diimbangi dengan jumlah produksi mendorong pemerintah membuka impor bawang merah. Impor dilakukan untuk menjaga keseimbangan harga dan pasokan bawang merah di pasaran domestik sehingga angka inflasi yang diakibatkan kenaikan harga bawang merah dapat ditekan. Impor yang tidak tepat jumlah akan mengakibat kerugian bagi pihak petani karena harga di pasaran terlalu murah tidak sebanding dengan biaya produksi yang dikeluarkan, untuk itu perlu adanya sistem yang dapat meramalkan kebutuhan impor bawang merah guna menjaga keseimbangan harga pasar dan pemenuhan kebutuhan bawang merah nasional.[1]

Sistem yang dirancang akan dibuat dengan menerapkan Fuzzy Inference System dengan metode Tsukamoto. Logika fuzzy dipilih karena Logika fuzzy merupakan salah satu metode pembentuk soft computing berbeda dengan conventional computing, yang memungkinkan toleransi terhadap input, proses dan output yang bersifat tidak akurat(imprecision), tidak pasti (uncertainty) dan setengah benar (partial truth). Logika fuzzy memiliki kemampuan penalaran secara bahasa sehingga dalam perancangannya tidak memerlukan persamaan matematika yang rumit. Logika fuzzy sering digunakan karena mudah dimengerti, memiliki toleransi terhadap datadata yang tidak tepat, mampu memodelkan fungsi-fungsi non linier yang kompleks, dapat membangun dan mengaplikasikan pengalaman para pakar secara langsung tanpa melalui proses pelatihan, dapat bekerjasama dengan teknik-teknik kendali konvensional dan didasarkan pada bahasa alami [2].

Metode fuzzy telah banyak diterapkan untuk peramalan dan perencanaan diantaranya adalah analisis fluktuasi dan prediksi harga beras menggunakan Fuzzy Cognitive Map (FCM) dilakukan untuk mengetahui harga beras di masa mendatang dengan memodelkan faktor-faktor berpengaruh terhadap harga beras.[3], perencanaan jumlah produksi mie instan di PT. Indofood CBP Sukses Makmur,Tbk dengan menggunakan metode fuzzy Mamdani [4], Menganalisis logika aplikasi fuzzy produksi perencanaan dalam menentukan jumlah produksi obat pada kuartal kedua 2013 (untuk Mei dan Juni) di PT. Kimia Farma (Persero) Tbk. Tanaman Bandung, dimana dari analisis perusahaan dapat disimpulkan bahwa metode fuzzy Tsukamoto lebih optimal karena jumlah kekurangan dan mendekati standar skala batch overproduksi setiap produk sehingga memudahkan bagi perusahaan untuk menghasilkan produk tanpa khawatir tentang sisa produk[5], Penerapan metode logika fuzzy dengan sistem inferensi fuzzy Sugeno untuk memprediksi laju inflasi berdasarkan variabel-variabel yang mempengaruhinya [6]

Penelitian ini bertujuan untuk merancang sistem pendukung keputusan dalam menentukan volume impor bawang merah dengan menerapkan Fuzzy Inference System. Metode fuzzy yang digunakan adalah metode Tsukamoto, dalam menentukan nilai impor bawang merah parameter input yang akan disertakan dalam penelitian adalah produksi, kebutuhan/konsumsi dan harga [7] ditambah dengan harga impor dan nilai tukar rupiah (kurs)[8]. Dalam proses pengelompokkan data latih menerapkan algoritma K-Means, K-Means sering digunakan karena kesederhanaan dan efisiensinya, penggunaan algoritma K-Means karena terbukti cukup handal dan banyak digunakan dalam komunitas penelitian data mining sebagaimana diungkapkan oleh Xindong Wu (2008) dalam survey paper yang berjudul "Top 10 Algorithm in Data Mining", top 10 algoritma data mining yang diidentifikasi oleh IEEE International Conference on Data Mining (ICDM) in December 2006 yaitu : C4.5, k-Means, SVM (Support Vector Machines), Apriori, EM, PageRank, AdaBoost, kNN, Naïve Bayes dan CART [9]. Tahapan pengembangan sistem 
Citec Journal, Vol. 2, No. 3, Mei 2015 - Juli 2015

ISSN: 2354-5771

menggunakan MSF (Microsoft Solution Framework) [10] fase yang dilakukan adalah Envisioning Phase, Planning Phase dan Developing phase. Implementasi penelitian ini menggunakan Microsoft Visual Studio 2008 dan Microsoft Access 2007.

\section{METODE PENELITIAN}

\subsection{Metode Penelitian}

Dalam penelitian ini menggunakan metodologi Participatory Action Design Research (PADR). PADR merupakan metodologi yang menggabungkan variasi pendekatan Action Research (AR) dan Design Research (DSR) untuk memenuhi urban informatics. [11]

\subsection{Metode Pengembangan Sistem}

Metode untuk kerangka pengembangan sistem yang diusulkan menggunakan Microsoft Solution Framework (MSF). [10]

\subsection{Metode Pengumpulan Data}

Dalam penelitian ini metode pengumpulan data menggunakan teknik observasi. Datadata yang dikumpulkan berupa bahan statistik yaitu data histori produksi, konsumsi, import dan harga bawang pada 5 tahun terakhir yang diperoleh dari beberapa sumber antara lain : Laporan Bulanan Data Sosial Ekonomi Badan Pusat Statistik, Pusat Data Kementrian Pertanian, Ditjen Pengolahan dan pemasaran hasil pertanian, dan sumber terkait lainnya.[12],[13],[14]

\subsection{Metode Analisis Data}

Metode penelitian yang dilakukan dalam pengelolahan dan menganalisa data ditunjukan dengan skema penelitian pada Gambar 1.

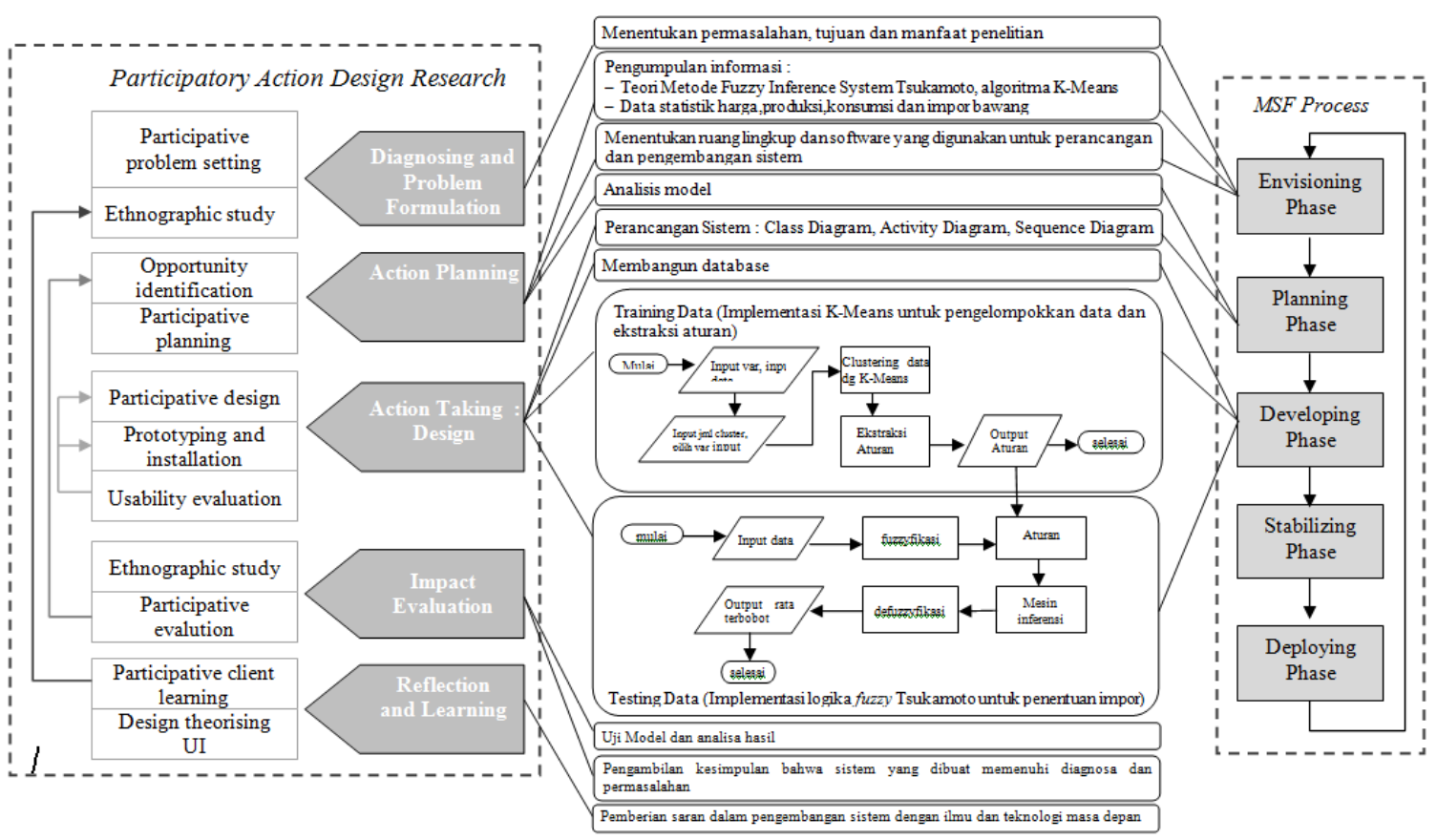

Gambar 1. Skema Penelitian 
Sistem yang dirancang merupakan sistem pendukung keputusan yang mengimplementasikan kecerdasan buatan berupa Fuzzy Inference System (FIS) Tsukamoto, yang dalam penelitian ini digunakan untuk menentukan volume impor bawang merah. Sistem yang dirancang memungkinkan pengguna untuk melakukan :

1. Training data dengan tahapan : (1) memasukkan variabel input dan output kasus yang akan diolah, (2) memasukkan data-data variabel input dan output yang akan dilatih dan diuji (3) melakukan clustering data, (4) mengekstraksi rule dari hasil clustering data, (5) menguji FIS dengan rule yang dihasilkan terhadap data latih.

2. Testing data, yaitu proses untuk menentukan output, dalam penelitian ini berupa volume impor bawang merah. Proses yang dilakukan pengguna adalah menginputkan data uji maka sistem akan melakukan proses fuzzy dengan mesin inferensi (rule) yang terbentuk dalam proses training dan menampilkan output berupa volume impor bawang merah.

\section{HASIL DAN PEMBAHASAN}

\subsection{Analisis Model}

Dalam pembentukan sistem inferensi fuzzy tsukamoto dilakukan tahapan pengelompokan data, ekstraksi rule, Penelusuran FIS Tsukamoto. Dari data yang ditampilkan pada tabel 1, data 1 sampai 60 digunakan sebagai data latih dan sisanya digunakan sebagai data uji.

\subsubsection{Pengelompokan data}

Proses pengklusteran data latih menggunakan algoritma K-Means. Adapun tujuan dari pengelompokkan ini adalah untuk meminimalkan fungsi objektif yang diset dalam proses pengelompokan, yang pada umumnya berusaha untuk meminimalkan variasi didalam suatu kelompok dan memaksimalkan variasi antar kelompok.[15]

Tabel 1. Data Harga, Produksi, Kebutuhan, kurs dan impor bawang merah Januari 2008- Juni 2014

\begin{tabular}{|r|l|r|r|r|r|r|r|r|}
\hline $\begin{array}{c}\text { No } \\
\text { Data }\end{array}$ & \multicolumn{1}{|c|}{ Ket } & HP & HK & \multicolumn{1}{|c|}{ PO } & KE & HI & KR & \multicolumn{1}{|c|}{ IM } \\
\hline 1 & Januari 2008 & 11242 & 14910 & 50289873 & 55853300 & 0.48 & 3870 & 12975700 \\
\hline 2 & Februari 2008 & 11025 & 14182 & 50778949 & 56352540 & 0.51 & 3654 & 14675650 \\
\hline 3 & Maret 2008 & 11613 & 14888 & 50704352 & 55983600 & 0.54 & 3807 & 11317800 \\
\hline 4 & April 2008 & 12107 & 15022 & 84989366 & 57078700 & 0.51 & 3888 & 5879758 \\
\hline 5 & Mei 2008 & 12556 & 15842 & 83767216 & 56971700 & 0.54 & 3984 & 3528760 \\
\hline 6 & Juni 2008 & 12717 & 15936 & 95166779 & 56967400 & 0.56 & 4148 & 2494350 \\
\hline 7 & Juli 2008 & 12070 & 15514 & 97598800 & 61456000 & 0.49 & 4773 & 5851480 \\
\hline 8 & Agustus 2008 & 11785 & 14781 & 96754076 & 62278920 & 0.51 & 3761 & 5570747 \\
\hline 9 & September 2008 & 11407 & 14123 & 87553458 & 63676300 & 0.54 & 3672 & 5543809 \\
\hline 10 & Januari 2008 & 10829 & 13781 & 52941105 & 56878000 & 0.52 & 5980 & 14067570 \\
\hline 11 & Nopember 2008 & 10576 & 13429 & 49347534 & 57950060 & 0.41 & 6269 & 15097600 \\
\hline 12 & Desember 2008 & 10885 & 13609 & 47723776 & 58811280 & 0.48 & 5906 & 14886700 \\
\hline 13 & Januari 2009 & 10280 & 11269 & 54296474 & 58685600 & 0.43 & 15605 & 9390600 \\
\hline 14 & Februari 2009 & 10707 & 11269 & 54381762 & 59483750 & 0.45 & 11268 & 12159900 \\
\hline 15 & Maret 2009 & 11272 & 14444 & 55489766 & 59836700 & 0.44 & 12422 & 9986050 \\
\hline 16 & April 2009 & 10934 & 13140 & 104621740 & 61588800 & 0.43 & 17451 & 623090 \\
\hline 17 & Mei 2009 & 10923 & 12911 & 103805876 & 61365300 & 0.45 & 6847 & 6331500 \\
\hline 18 & Juni 2009 & 10631 & 12417 & 104242435 & 62276000 & 0.41 & 12744 & 2985200 \\
\hline 19 & Juli 2009 & 11137 & 13887 & 98373250 & 62767700 & 0.42 & 10596 & 6815500 \\
\hline 20 & Agustus 2009 & 11488 & 14748 & 99794165 & 64973700 & 0.42 & 8436 & 5374700 \\
\hline
\end{tabular}


Citec Journal, Vol. 2, No. 3, Mei 2015 - Juli 2015

Tabel 1 (Lanjutan)

\begin{tabular}{|c|c|c|c|c|c|c|c|c|}
\hline $\begin{array}{l}\text { No } \\
\text { Data }\end{array}$ & Ket & HP & HK & PO & $\mathbf{K E}$ & HI & $\mathbf{K R}$ & IM \\
\hline 21 & September 2009 & 11281 & 12106 & 93755626 & 66650700 & 0.28 & 10647 & 2975400 \\
\hline 22 & Oktober 2009 & 10898 & 11036 & 65435427 & 61098800 & 0.33 & 2470 & 7532700 \\
\hline 23 & Nopember 2009 & 10932 & 12265 & 67475311 & 61574300 & 0.48 & 26747 & 3058900 \\
\hline 24 & Desember 2009 & 10946 & 12952 & 65492300 & 61374130 & 0.52 & 10000 & 8767800 \\
\hline 25 & Januari 2010 & 10707 & 12871 & 74052300 & 61576300 & 0.51 & 12864 & 6259000 \\
\hline 26 & Februari 2010 & 10729 & 13288 & 75120200 & 62276000 & 0.49 & 1609 & 8748900 \\
\hline 27 & Maret 2010 & 10770 & 13713 & 75131550 & 62174630 & 0.44 & 6931 & 7648900 \\
\hline 28 & April 2010 & 11152 & 14105 & 78965490 & 62978380 & 0.47 & 4274 & 5842800 \\
\hline 29 & Mei 2010 & 11111 & 14098 & 78721408 & 64746200 & 0.45 & 884 & 6513550 \\
\hline 30 & Juni 2010 & 11374 & 16654 & 79242560 & 66885000 & 0.41 & 1614 & 2165670 \\
\hline 31 & Juli 2010 & 12739 & 20611 & 107627100 & 65115800 & 0.35 & 5065 & 3477870 \\
\hline 32 & Agustus 2010 & 12197 & 18733 & 115347175 & 67675500 & 0.47 & 6225 & 1436720 \\
\hline 33 & September 2010 & 12112 & 16339 & 105566767 & 70798240 & 0.48 & 5924 & 2983510 \\
\hline 34 & Oktober 2010 & 12301 & 18299 & 82775550 & 67930000 & 0.47 & 4136 & 7809530 \\
\hline 35 & Nopember 2010 & 12891 & 22337 & 81605936 & 66089000 & 0.48 & 3950 & 6674900 \\
\hline 36 & Desember 2010 & 13003 & 23648 & 81793520 & 68078000 & 0.48 & 4655 & 7790000 \\
\hline 37 & Januari 2011 & 12892 & 24056 & 46325135 & 69574000 & 0.48 & 8931 & 22724292 \\
\hline 38 & Februari 2011 & 13149 & 24710 & 45215245 & 70293000 & 0.51 & 8997 & 29636120 \\
\hline 39 & Maret 2011 & 13687 & 24214 & 44107387 & 70161000 & 0.54 & 8780 & 31879235 \\
\hline 40 & April 2011 & 13385 & 18320 & 65597639 & 70693000 & 0.51 & 8656 & 11187467 \\
\hline 41 & Mei 2011 & 12877 & 17926 & 63875735 & 69704000 & 0.53 & 8511 & 9578389 \\
\hline 42 & Juni 2011 & 12976 & 19943 & 65278899 & 74715000 & 0.56 & 8497 & 22832689 \\
\hline 43 & Juli 2011 & 13361 & 21282 & 99127000 & 74567000 & 0.5 & 8520 & 10722910 \\
\hline 44 & Agustus 2011 & 13085 & 17672 & 97345000 & 75768000 & 0.51 & 8495 & 4847780 \\
\hline 45 & September 2011 & 12617 & 15742 & 102961000 & 75534000 & 0.55 & 8530 & 2384780 \\
\hline 46 & Oktober 2011 & 12442 & 14643 & 83644356 & 71574000 & 0.53 & 8915 & 6395873 \\
\hline 47 & Nopember 2011 & 12450 & 14065 & 81989469 & 71693000 & 0.42 & 9930 & 7735789 \\
\hline 48 & Desember 2011 & 12244 & 13388 & 79867228 & 72704000 & 0.48 & 9057 & 10757874 \\
\hline 49 & Januari 2012 & 10393 & 12594 & 74267000 & 72237000 & 0.43 & 9134 & 8086420 \\
\hline 50 & Februari 2012 & 9514 & 12639 & 77575470 & 73363000 & 0.45 & 9950 & 9437800 \\
\hline 51 & Maret 2012 & 10491 & 12692 & 75678670 & 72934900 & 0.44 & 9144 & 8836580 \\
\hline 52 & April 2012 & 12295 & 13910 & 79675000 & 74857000 & 0.47 & 9122 & 10504330 \\
\hline 53 & Mei 2012 & 16190 & 17334 & 71271000 & 74276000 & 0.45 & 9179 & 16479999 \\
\hline 54 & Juni 2012 & 14590 & 17715 & 68122000 & 76233000 & 0.41 & 9416 & 28716910 \\
\hline 55 & Juli 2012 & 13175 & 15376 & 98576243 & 75052100 & 0.42 & 9538 & 6651339 \\
\hline 56 & Agustus 2012 & 11834 & 13449 & 100859234 & 90055585 & 0.41 & 9438 & 2765378 \\
\hline 57 & September 2012 & 11639 & 12783 & 103532527 & 91120000 & 0.26 & 9833 & 2578355 \\
\hline 58 & Oktober 2012 & 9949 & 12150 & 95386376 & 77431900 & 0.33 & 9545 & 5175345 \\
\hline 59 & Nopember 2012 & 12656 & 14271 & 79965740 & 74787520 & 0.49 & 9580 & 7385381 \\
\hline 60 & Desember 2012 & 15363 & 16507 & 75173670 & 76324600 & 0.58 & 9557 & 8074540 \\
\hline 61 & Januari 2013 & 12000 & 20305 & 83978465 & 75865420 & 0.51 & 9637 & 2755450 \\
\hline 62 & Februari 2013 & 10081 & 18306 & 77587210 & 75756997 & 0.49 & 9649 & 5148010 \\
\hline 63 & Maret 2013 & 26005 & 32528 & 80088659 & 75082400 & 0.44 & 9676 & 6068800 \\
\hline 64 & April 2013 & 25000 & 34111 & 49863567 & 76125070 & 0.47 & 10157 & 15004330 \\
\hline 65 & Mei 2013 & 22336 & 30641 & 48078954 & 75839350 & 0.45 & 9681 & 22479999 \\
\hline 66 & Juni 2013 & 24416 & 32641 & 49757590 & 75975300 & 0.41 & 9762 & 13716911 \\
\hline 67 & Juli 2013 & 42684 & 49207 & 88868543 & 76923840 & 0.44 & 9890 & 2738809 \\
\hline 68 & Agustus 2013 & 51438 & 60549 & 91576500 & 78543540 & 0.47 & 10237 & 5626935 \\
\hline 69 & September 2013 & 25568 & 33873 & 86276000 & 78213200 & 0.48 & 10928 & 4373786 \\
\hline 70 & Oktober 2013 & 17987 & 26212 & 84433000 & 75939800 & 0.75 & 11535 & 3720464 \\
\hline
\end{tabular}


Langkah-langkah didalam K-Means adalah sebagai berikut:

1. Tentukan jumlah kelompok

2. Alokasi data ke dalam kelompok secara acak

3. Hitung pusat kelompok (sentroid/rata=rata) dari data yang ada di masing-masing kelompok

$$
\mathrm{C}_{\mathrm{i}}=\frac{1}{\mathrm{M}} \quad \sum_{\mathrm{j}=1}^{\mathrm{M}} \mathrm{X}_{\mathrm{j}}
$$

Dimana $\mathrm{M}$ adalah jumlah data didalam kelompok, i menyatakan fitur ke-i dalam sebuah kelompok dan $\mathrm{p}$ menyatakan $\mathrm{b}$ dimensi data.

Cara mengukur jarak terdekat ke pusat kelompok menggunakan formula Eucliadean yaitu:

$$
\mathrm{D}\left(\mathrm{X}_{1}, \mathrm{X}_{2}\right)=\left\|\mathrm{X}_{1}-\mathrm{X}_{2}\right\|^{2}=\sqrt{\sum_{\mathrm{j}=1}^{\mathrm{p}}\left|\mathrm{X}_{2 \mathrm{j}}-\mathrm{X}_{1 \mathrm{j}}\right|^{2}}
$$

4. Alokasi data ke dalam sentroid terdekat

Didasarkan pada perbandingan jarak antara data dengan pusat setiap sentroid kelompok yang ada. Data dialokasikan secara tegas ke kelompok yang mempunyai jarak terdekat dari data tersebut.

$$
a_{i 1}=\left\{\begin{array}{lr}
1 & d=\min \left\{D\left(x_{i}, C_{1}\right)\right\} \\
0 & \text { lainnya }
\end{array}\right.
$$

Fungsi objektif yang digunakan untuk K-Means ditentukan berdasarkan jarak dan nilai keanggotaan data dalam kelompok, yaitu sebagai berikut :

$$
\mathrm{J}=\sum_{\mathrm{i}=1}^{\mathrm{n}} \sum_{1=1}^{\mathrm{k}} \mathrm{a}_{\mathrm{ic}} \mathrm{D}\left(\mathrm{x}_{\mathrm{i}}, \mathrm{C}_{1}\right)^{2}
$$

5. Kembali ke langkah 3, apabila masih ada data yang berpindah kelompok, atau apabila ada perubahan nilai sentroid di atas nilai ambang yang ditentukan, atau apabila perubahan nilai pada fungsi objektif yang digunakan masih di atas nilai yang ditentukan.

Contoh hasil pengklusteran dengan algoritma K-Means tampak pada gambar 2.

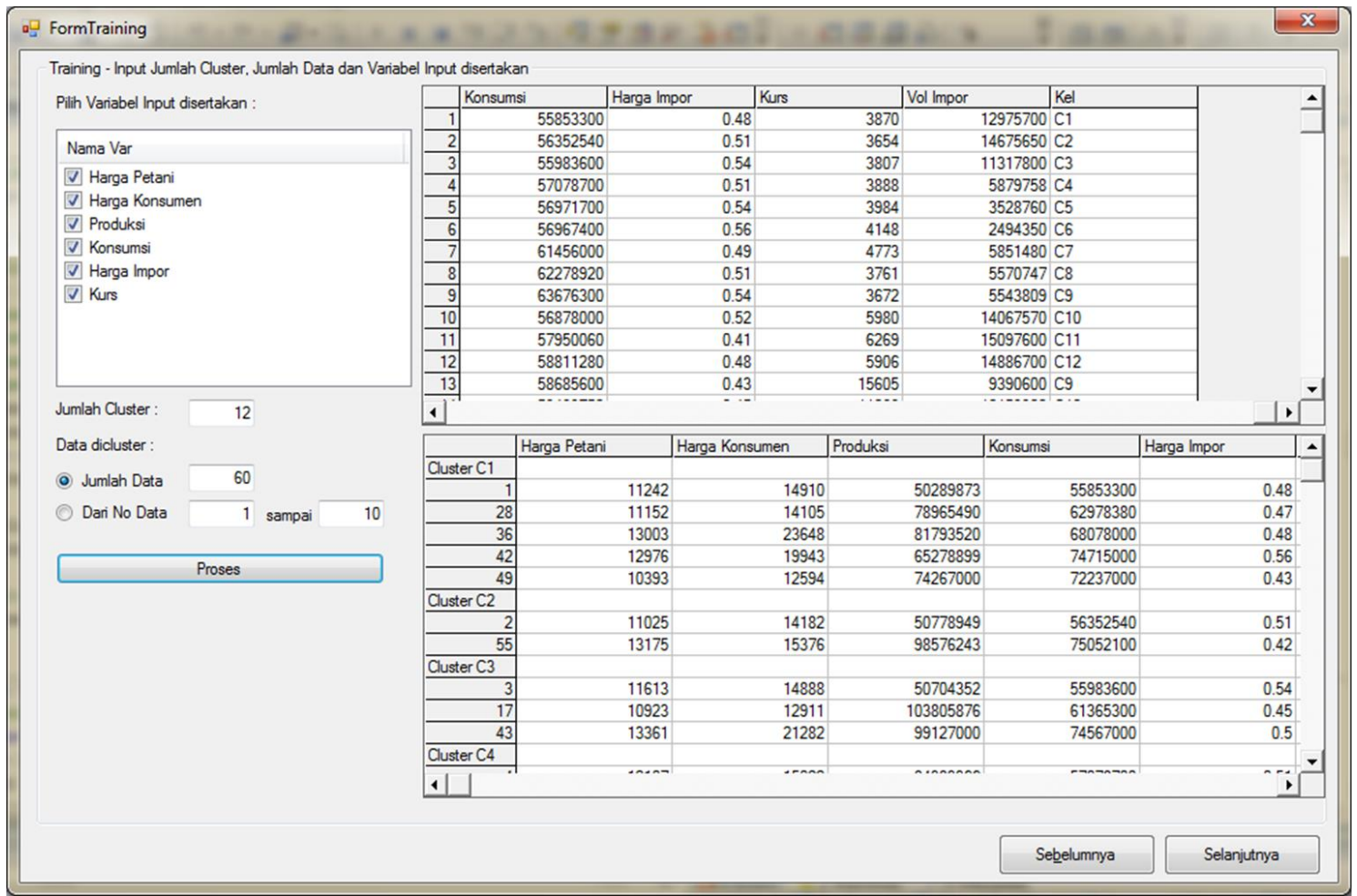

Gambar 2. Tampilan Output Clustering K-Means 


\subsubsection{Ekstraksi Aturan}

Aturan fuzzy selain diperoleh dari ahli manusia juga bisa dibentuk dari hasil clustering. Sebelumnya data yang ada dipisahkan antara data pada variabel input dan data pada variabel output. Misalkan jumlah variabel input adalah $m$ dan variabel output biasanya ada 1 . Sistem inferensi fuzzy dengan metode Tsukamoto. Misalkan aturan yang dimiliki sebagai berikut:

$$
\begin{aligned}
& \text { IF } x_{1} \text { is } A_{1} \text { AND } x_{2} \text { is } B_{1} \text { THEN } y_{1}=q_{1} w_{1}+p_{1} \\
& \text { IF } x_{1} \text { is } A_{2} \text { AND } x_{2} \text { is } B_{2} \text { THEN } y_{2}=q_{2} w_{2}+p_{2}
\end{aligned}
$$

Proses pembangkitan aturan fuzzy (IF-THEN) dilakukan dengan proses pencarian output melalui langkah-langkah berikut [16]:

1. Dari hasil clustering kemudian dilakukan perhitungan nilai standar deviasi $(\sigma)$ dihitung berdasarkan persamaan berikut.

$$
\sigma=\sqrt{\frac{\sum_{\mathrm{i}=1}^{\mathrm{n}}\left(\mathrm{x}_{\mathrm{i}}-\overline{\mathrm{x}}_{\mathrm{c}}\right)^{2}}{\mathrm{n}_{\mathrm{c}}-1}}
$$

Dimana $\sigma=$ standar deviasi, $\mathrm{x}_{\mathrm{i}}=$ data ke-i, $\bar{x}_{c}=$ mean (rata-rata dari data pada suatu cluster) dan $\mathrm{n}_{\mathrm{c}}=$ jumlah data pada suatu cluster.

2. Hitung derajat fungsi keanggotaan

3. Kemudian derajat keanggotaan setiap data $i$ dalam cluster $k\left(\mu_{\mathrm{ik}}\right)$ dikalikan.

$$
\mathrm{W}_{\mathrm{k}}=\left(\mu \mathrm{x}_{1} \mathrm{k}\right)\left(\mu \mathrm{x}_{2} \mathrm{k}\right) \ldots\left(\mu \mathrm{x}_{1 \mathrm{n}} \mathrm{k}\right)
$$

4. Melakukan normalisasi untuk mendapatkan $\bar{w}_{1}, \bar{w}_{2}, \ldots \bar{w}_{i}$ dengan persamaan berikut :

$$
\overline{\mathrm{w}}_{\mathrm{i}}=\frac{\mathrm{w}_{\mathrm{i}}}{\mathrm{w}_{1}+\mathrm{w}_{2}+\cdots+\mathrm{w}_{\mathrm{n}}}
$$

5. Menghitung koefisien dari $\mathrm{p}$ dan $\mathrm{q}$ :

$$
\begin{aligned}
& \mathrm{q}_{\text {in }} \rightarrow\left(\overline{\mathrm{w}}_{\text {in }}\right)\left(\mathrm{w}_{\mathrm{in}}\right) \\
& \mathrm{p}_{\mathrm{in}} \rightarrow\left(\overline{\mathrm{w}}_{\mathrm{in}}\right)
\end{aligned}
$$

6. Mencari nilai parameter-parameter $\mathrm{p}_{\mathrm{n}}$ dan $\mathrm{q}_{\mathrm{n}}$ dengan menggunakan LSE rekursif berdasarkan persamaan berikut :

$$
\begin{aligned}
& \mathrm{P}_{\mathrm{n}}=\left(\mathrm{A}_{\mathrm{n}}^{\mathrm{T}} \mathrm{A}_{\mathrm{n}}\right)^{-1} \\
& \theta_{\mathrm{n}}=\mathrm{P}_{\mathrm{n}} A_{\mathrm{n}}^{\mathrm{T}} \mathrm{Y}_{\mathrm{n}}
\end{aligned}
$$


Hasil Ektraksi aturan tampak pada gambar 4, dimana nilai yang dihasilkan berupa nilai q dan $\mathrm{p}$ pada masing-masing rule.

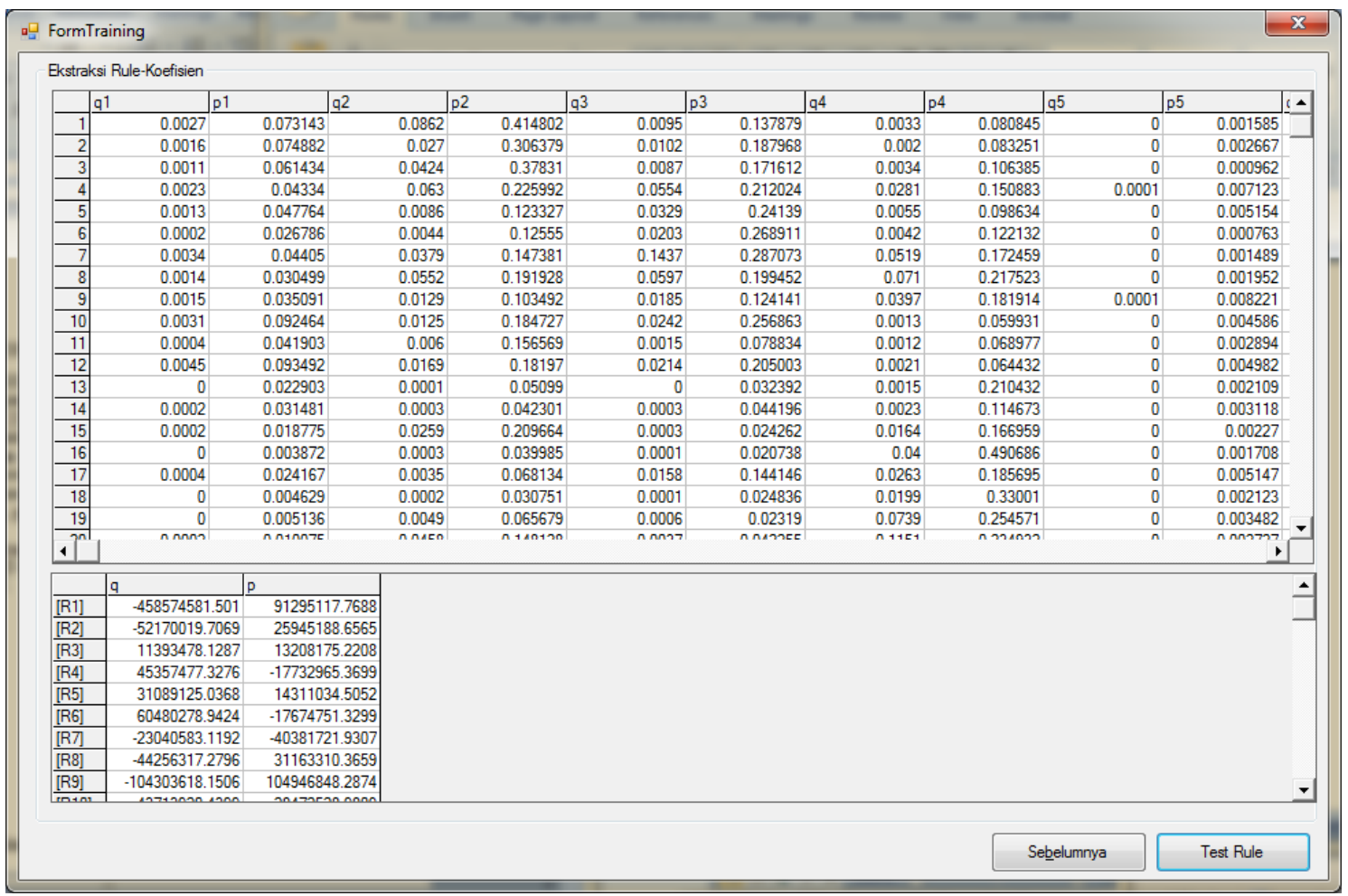

Gambar 3. Tampilan Output Hasil Ekstraksi Aturan

\subsubsection{Uji FIS Tsukamoto}

Langkah-langkah dalam pengujian FIS Tsukamoto adalah sebagai berikut:

1. Fuzzyfikasi

Menghitung derajat fungsi keanggotaan dengan kurva bentuk lonceng yaitu kurva Beta, didefinisikan dengan dua parameter yaitu nilai pada domain yang menunjukkan pusat kurva $(\gamma)$ dan setengah lebar kurva $(\beta)$.

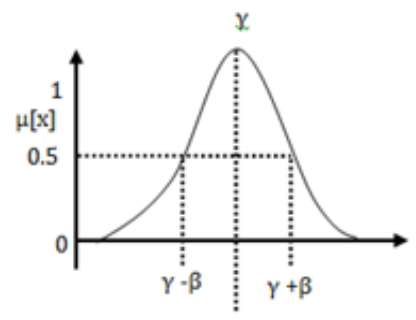

Gambar 4. Kurva Beta

Fungsi Keanggotaan himpunan fuzzy ini adalah:

$$
B(x ; \gamma ; \beta)=\frac{1}{1+\left(\frac{x-\gamma}{\beta}\right)^{2}}
$$

2. Rule

Rule yang digunakan adalah rule hasil training data latih.

3. Mesin Inferensi, pada mesin inferensi, dterapkan fungsi PRODUCT untuk setiap aturan pada aplikasi fungsi implikasinya.

4. Defuzzyfikasi 
Citec Journal, Vol. 2, No. 3, Mei 2015 - Juli 2015

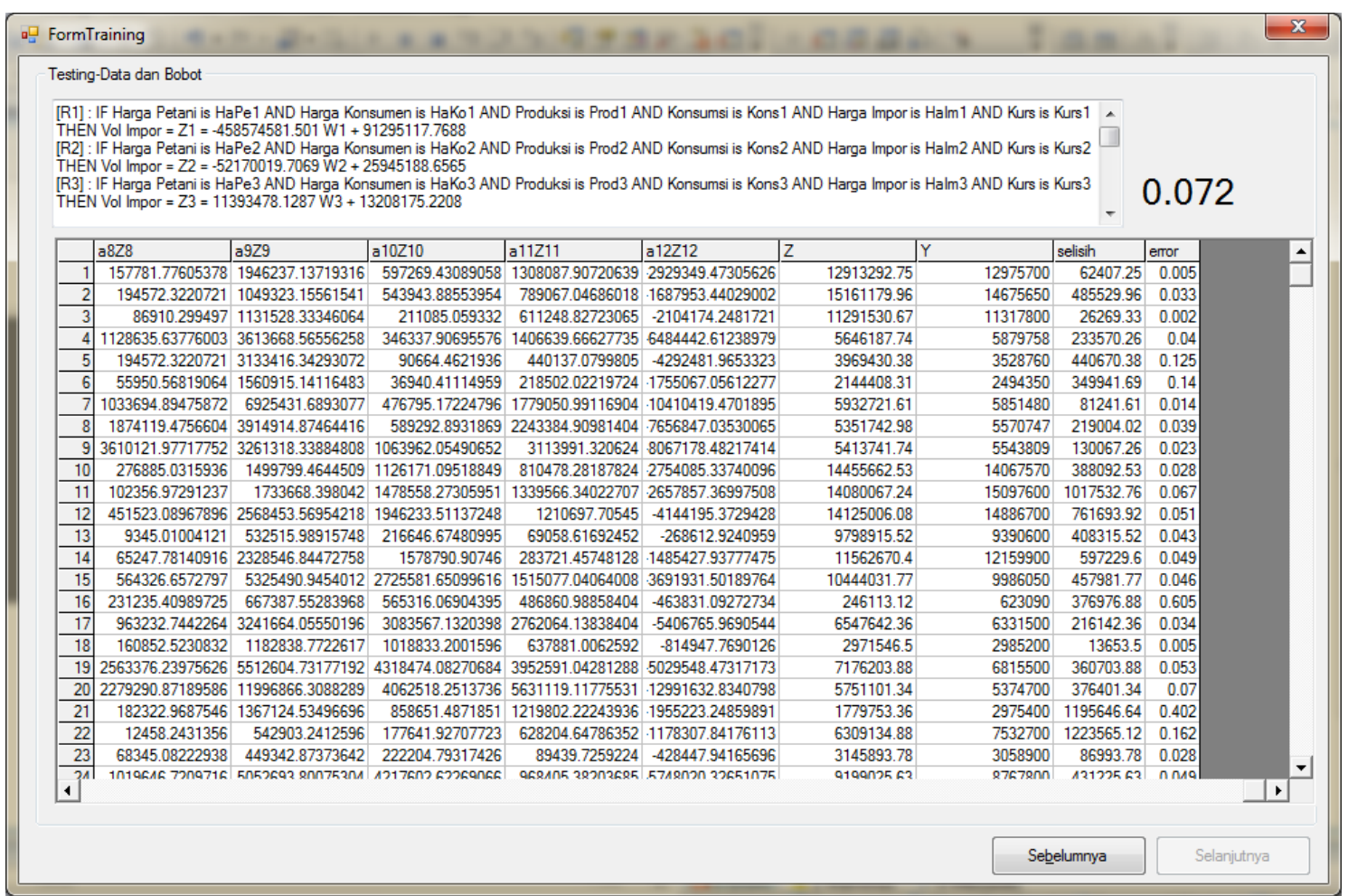

Gambar 5. Tampilan Output FIS Tsukamoto pada 60 Data Latih

Pada gambar 5 hasil uji fuzzy tsukamoto terhadap data latih menghasilkan rata-rata error 0.072. sedangkan hasil uji terhadap 5 data uji memiliki rata-rata error 0.252 dengan error terkecil pada data ke-2 yaitu error sebesar 0.08 dan error terbesar pada data ke- 5 sebesar 0.356 seperti yang ditampilkan pada gambar 6.

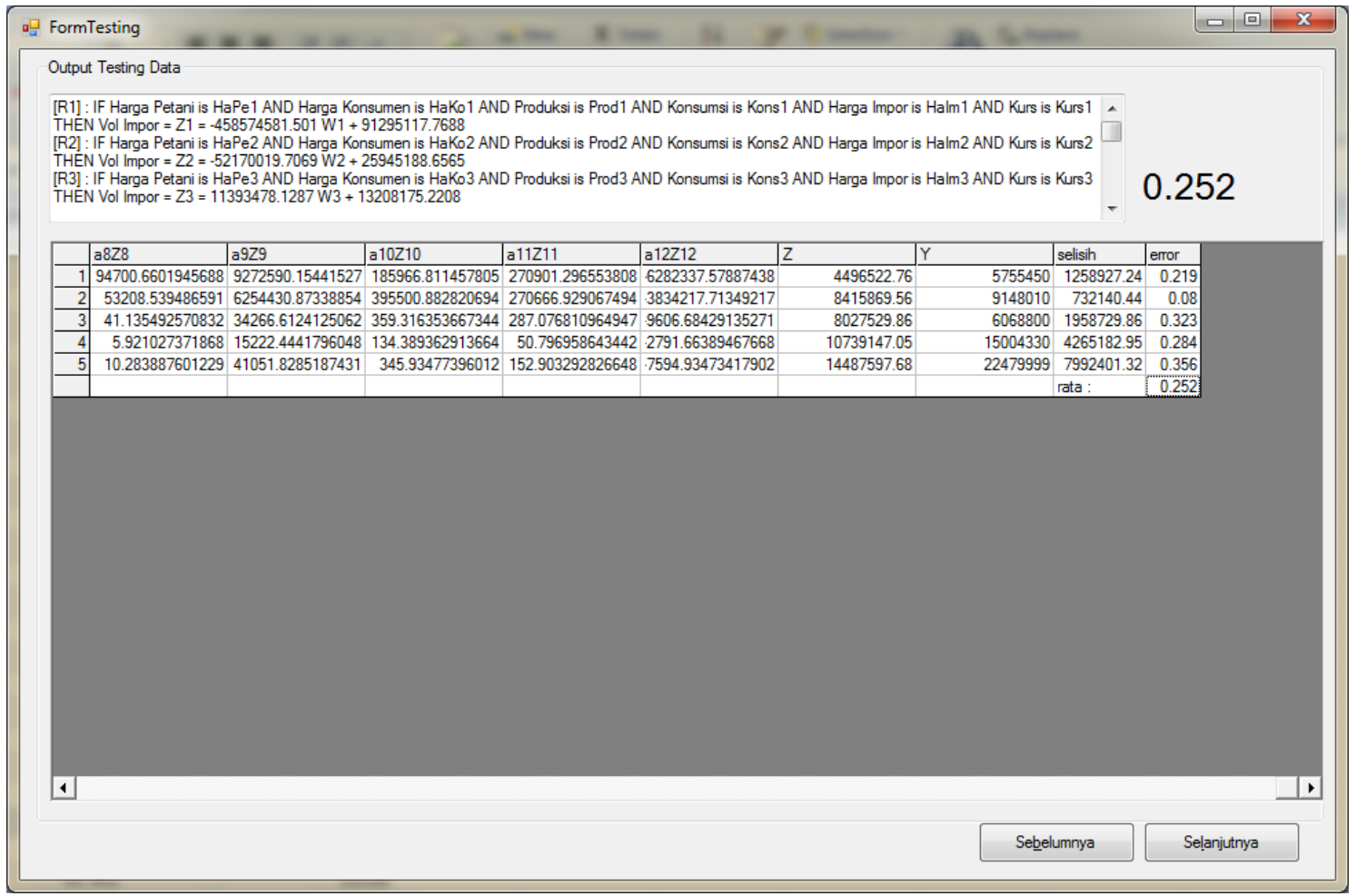

Gambar 6. Tampilan output FIS Tsukamoto pada 5 Data Uji 
Pengujian model dilakukan pada 60 data latih, rata error yang dihasilkan dari hasil uji coba ditampilkan pada tabel 2, dari tabel tersebut error terkecil diperoleh pada jumlah Cluster 12.

Tabel 2. Rata-rata Error pada uji model

\begin{tabular}{|c|c|c|c|}
\hline No & Var input disertakan & Jml Cluster & Rata-Rata Error \\
\hline \multirow{12}{*}{1} & \multirow{12}{*}{$\begin{array}{l}6 \text { variabel input: } \\
\text { Harga Petani } \mathrm{x}_{1} \text {, Harga Konsumen } \mathrm{x}_{2} \text {, Produksi } \mathrm{x}_{3} \text {, } \\
\text { Konsumsi } \mathrm{x}_{4} \text {, harga impor } \mathrm{x}_{5} \text {, kurs } \mathrm{x}_{6}\end{array}$} & 2 & 0.315 \\
\hline & & 3 & 0.318 \\
\hline & & 4 & 0.31 \\
\hline & & 5 & 0.242 \\
\hline & & 6 & 0.275 \\
\hline & & 7 & 0.275 \\
\hline & & 8 & 0.263 \\
\hline & & 9 & 0.208 \\
\hline & & 10 & 0.19 \\
\hline & & 11 & 0.15 \\
\hline & & 12 & 0.072 \\
\hline & & 13 & 0.13 \\
\hline
\end{tabular}

\section{KESIMPULAN}

Kesimpulan yang diperoleh dari penelitian ini adalah :

1. Untuk merancang sistem pendukung keputusan penentuan impor bawang merah dengan menerapkan FIS Tsukamoto, sistem dilakukan dibagi menjadi 2 tahapan yaitu training data dan testing data. Training data dimaksudkan untuk membentuk aturan FIS Tsukamoto dan testing data ditujukan untuk menghitung output dengan metode fuzzy Tsukamoto. Pada tahapan Training data proses yang dilakukan yaitu (1) menginputkan variabel input dan output, (2) menginputkan pasangan data semua variabel input dan output, (3) mengkluster data, (4) mengekstraksi cluster menjadi aturan fuzzy. Selanjutnya adalah melakukan penentuan nilai impor dengan tahapan FIS Tsukamoto.

2. Uji Model dengan metode FIS Tsukamoto dilakukan terhadap data latih dan data uji, dengan rule yang dihasilkan dari proses training data dengan menggunakan 60 data latih error minimal dihasilkan dengan jumlah cluster 12 cluster yang menghasilkan nilai error rata-rata sebesar 0.072 sedangkan pada data uji menghasilkan nilai error rata sebesar 0.252 .

\section{SARAN}

Saran untuk pengembangan lebih lanjut dari penelitian ini adalah:

1. Penerapan algoritma pengclusteran yang tidak terawasi seperti Fuzzy Subtractive Clustering karena jumlah cluster yang akan dibentuk belum diketahui sebelumnya sehingga tidak perlu menguji coba sejumlah cluster.

2. Dalam proses pembentukan aturan (rule), dapat ditambahkan dengan algoritma pembelajaran hybrid untuk bisa menurunkan nilai error yang terjadi pada setiap lapisan proses pembentukan rule, dimana hal ini memungkinkan aturan-aturan yang terbentuk untuk beradaptasi atau yang biasa dikenal dengan Adaptive Neuro Fuzzy Inference System, baik menggunakan ANFIS Tsukamoto maupun ANFIS Sugeno.

\section{DAFTAR PUSTAKA}

[1] Rusono, N., Suanri, A., Candradijaya., 2014, Rencana Pembangunan Jangka Menengah Nasional (RPJMN) Bidang Pangan dan Pertanian 2015-2019, www.bappenas.go.id/index.php/download_file/view/15718/4661, diakses 6 Agustus 2014. 
[2] Sutojo, T., Mulyanto, E., Suhartono, V., 2011, Kecerdasan Buatan, Andi Offset, Yogyakarta.

[3] Fithri Y, Suryani E \& Vinarti R, 2014, Analisis Fluktuasi dan Prediksi Harga Beras menggunakan Fuzzy Cognitive Maps untuk meningkatkan Kesejahteraan Petani Beras, Jurnal Teknik POMITS Vol.1 No.1(1012), Surabaya.

[4] Zendrato E. N., Darnius O., Sembiring P., 2014, Perencanaan Jumlah Produksi Mie Instan Dengan Penegasan (Defuzzifikasi)Centroid Fuzzy Mamdani (Studi Kasus: Jumlah Produksi Indomie di PT. Indofood CBP Sukses Makmur, Tbk Tanjung Morawa), Saintia Matematika, No. 2, Vol. 2, Hal 115-126.

[5] Firmansyah, I., \& Utami, S. F., 2013, Tsukamoto Fuzzy Logic Application in Production Planning at PT. Kimia Farma (Persero) Tbk. Plant Bandung Indonesia, Proceedings The 2nd International Conference On Global Optimization and Its Applications 201, Avillion Legacy Melaka Hotel, Malaysia.

[6] Purnama, P, A., 2014, Aplikasi Sistem Inferensi Fuzzy Sugeno Dalam Memprediksi Laju Inflasi (Studi Kasus Pada Data Inflasi Indonesia Dan Bali), Jurnal Mahasiswa Statistik, No 4, Vol 1, hal 273-276.

[7] Meliala, M, Br., 2014, Faktor-Faktor Yang Mempengaruhi Volume Impor dan Kebijakan Impor Bawang Merah (A. Ascalonicum L.) Indonesia, Skripsi, Departemen Agribisnis Fakultas Ekonomi dan Manajemen, Institut Pertanian Bogor, Bogor.

[8] Pamungkas A. R., 2013, Pengaruh Produksi, Konsumsi Dan Harga Terhadap Impor Bawang Merah Di Kabupaten Brebes Tahun (2006.01 - 2010.12), Skripsi, Jurusan Ekonomi Pembangunan Fakultas Ekonomi, Universitas Negeri Semarang, Semarang.

[9] Wu, X., Kumar, V., Quinlan Ross, J., Ghosh, J.,Yang, Q., Motoda, H., McLachlan, J. G., Ng A., Liu, B., Yu, S. P., Zhou, Z., Steinbach, M., Hand, J. D., Steinberg., 2008, Top 10 algorithms in data mining, Springer, Knowl Inf Syst(2008) 14:1-37.

[10] Migunani, 2007, Microsoft Solution Framework Sebagai Model Proses Pengembangan Perangkat Lunak Berbasis Milestone, Tinjauan Pada Fase Envisioning dan Planing, Jurnal Teknologi Informasi DINAMIK, Vol 12, No.2, hal 144-153.

[11] Bilandzic, M., Venable, J., 2011, Towards Participatory Action Design Research: Adapting Action Research and Design Science Research Methods for Urban Informatics, The Journal of Community Informatics, No. 3, Vol. 7.

[12] Badan Pusat Statistik, 2014, Laporan Bulanan Data Sosial dan Ekonomi Edisi 45 Februari, Badan Pusat Statistik, Jakarta, www.bps.go.id, diakses 6 Agustus 2014

[13] Bank Indonesia, 2014, Informasi Kurs, Kurs Transaksi Bank Indonesia 1 Januari 2009-1 September 2014, http://www.bi.go.id/id/moneter/informasi-kurs/transaksi-bi/Default.aspx, diakses 6 Agustus 2014.

[14] Pusat Data dan Sistem Informasi Pertanian Kementrian Pertanian, 2014, database deptan.go.id/eksim2012asp/hasilimporKomoditi.asp, diakses 5 Agustus 2014.

[15] Prasetyo, E., 2012, Data Mining Konsep dan Aplikasi Menggunakan MatLab, Andi Offset, Yogyakarta.

[16] Kusumadewi, S., Hartati, S., 2010, Neuro-Fuzzy Integritas Sistem Fuzzy \& Jaringan Syaraf Edisi 2, Graha Ilmu, Yogyakarta. 